\title{
Neokestose suppresses the growth of human melanoma A2058 cells via inhibition of the nuclear factor- $\kappa B$ signaling pathway
}

\author{
JIANN-SHING WU ${ }^{1}$, JAN-YI CHANG ${ }^{2}$, C. WILL CHEN ${ }^{2}$, MING-TSE LIN ${ }^{2}$, DEY-CHYI SHEU ${ }^{2}$ and SHUN-MEI LEE ${ }^{2}$ \\ ${ }^{1}$ Department of Styling and Cosmetology, Hsin Shen Junior College of Medical Care and Management, \\ Taoyuan 325; ${ }^{2}$ Department of Bioengineering, Tatung University, Taipei 104, Taiwan, R.O.C.
}

Received February 22, 2016; Accepted February 21, 2017

DOI: $10.3892 / \mathrm{mmr} .2017 .6594$

\begin{abstract}
Neokestose has superior prebiotic effects compared with the commercial fructooligosaccharides (FOS). In addition, the branched structure of neokestose, a type of neo-FOS, confers improved chemical stability compared with conventional FOS; therefore, the investigation of the branched structure by the present study may be of high biomedical value. The present study aimed to determine whether neokestose may suppress growth of the A2058 melanoma cell line. The cells were initially treated with neokestose; subsequently, in vitro cytotoxicity was assessed using MTT, and cell cycle progression and apoptosis were detected using flow cytometry. The protein expression levels of cyclin D1, phosphorylated (p)-inhibitor of $\kappa \mathrm{B}(\mathrm{I} \kappa \mathrm{B})$ and nuclear factor- $\kappa \mathrm{B}(\mathrm{NF}-\kappa \mathrm{B})$ were determined using western blotting. Treatment with neokestose led to a dose-dependent inhibition of cell viability. Flow cytometry data indicated that neokestose increased the sub- $\mathrm{G}_{1}$ cell population, and induced early and late apoptosis. Western blot analysis revealed that neokestose treatment reduced the expression levels of $\mathrm{p}-\mathrm{I} \kappa \mathrm{B}$ and cyclin D1. These findings suggest that neokestose treatment may induce suppression of A2058 melanoma cell viability via inhibition of the $\mathrm{NF}-\kappa \mathrm{B}$ pathway. The present findings support the requirement for further investigation into the potential use of neokestose as an additional or chemopreventive therapeutic agent for the treatment of melanoma.
\end{abstract}

\section{Introduction}

Melanoma is a life-threatening form of skin cancer. In the last decade, its annual worldwide incidence has increased more rapidly compared with other solid tumors. Approximately 160,000 cases of malignant melanoma are newly diagnosed

Correspondence to: Professor Dey-Chyi Sheu or Miss Shun-Mei Lee, Department of Bioengineering, Tatung University, 40 Section 3 Zhongshan North Road, Taipei 104, Taiwan, R.O.C.

E-mail: dcsheu@ttu.edu.tw

E-mail: leyuko@yahoo.com.hk

Key words: melanoma, A2058 cells, neokestose, nuclear factor- $\kappa \mathrm{B}$ annually and $\sim 48,000$ patients succumb to malignant melanoma each year worldwide (1). The incidence of melanoma is less common compared with other types of skin cancer, including basal and squamous cell cancer. When malignant melanoma is diagnosed at an early stage (stage 0/1), the 5-year survival rate is $>90 \%$, following surgical excision. However, when malignant melanoma is diagnosed at a later stage, it is more invasive and lethal compared with other skin cancers. The median overall survival rate for patients with metastatic melanoma is $<1$ year (2).

The poor prognosis of metastatic melanoma presents a clinical challenge. Previous clinical studies have been conducted to improve the efficacy of melanoma treatment $(3,4)$. The US Food and Drug Administration has approved seven novel agents since 2011, including B-Raf proto-oncogene, serine/threonine kinase (BRAF)-inhibitors (vemurafenib, dabrafenib), MEK-inhibitors (trametinib), anti-programmed cell death protein 1 antibodies (nivolumab, pembrolizumab), anti-cytotoxic T-lymphocyte-associated protein 4 antibody (ipilimumab) and (peginterferon-alfa-2b); all of which are intended for use in the most advanced cases of melanoma (5). However, drug resistance is a frequent problem with this type of treatment. Therefore, it is necessary to develop novel treatment methods and identify novel drugs directed specifically at human malignant melanoma.

The cause of melanoma is difficult to determine; however, sun exposure and genetic susceptibility are considered to be important risk factors. Solar ultraviolet exposure, particularly when combined with sunburn, is the most important risk factor for the development of cutaneous malignant melanoma (6). Previous in vitro and in vivo studies have reported that nuclear factor $-\kappa \mathrm{B}(\mathrm{NF}-\kappa \mathrm{B})$ activity may be upregulated in dysplastic nevi and lesions of human melanoma compared with human nevi or melanocytes in normal skin (7-9). NF- $\kappa \mathrm{B}$ is a transcription factor that is associated with the activation of several cell processes, including cell growth and apoptosis (10). This factor is activated in various cell types in response to numerous stimuli, including mitogens, inflammatory cytokines and extracellular stress. These extracellular signals activate inhibitor of $\kappa \mathrm{B}(\mathrm{I} \kappa \mathrm{B})$ kinase (IKK). IKK, in turn, phosphorylates the I $\mathrm{B} \alpha$ protein, which leads to ubiquitination, dissociation of $\mathrm{I} \kappa \mathrm{B} \alpha$ from $\mathrm{NF}-\kappa \mathrm{B}$ and $\mathrm{I} \kappa \mathrm{B} \alpha$ degradation by proteasomes. The activated $\mathrm{NF}-\kappa \mathrm{B}$ is subsequently translocated into the nucleus. NF- $\kappa \mathrm{B}$ is an 
important cell cycle regulator the activity of which may result in increased cell growth (11).

Cyclin D1 is a protein that regulates the $\mathrm{G}_{1} / \mathrm{S}$ phase transition. During the $G_{1}$ phase, it is synthesized rapidly and accumulates in the nucleus. Cyclin D1 regulates the activity of cyclin-dependent kinases (CDKs), leading to phosphorylation of retinoblastoma protein $(\mathrm{Rb})$ and promotion of cell cycle progression (12). The p16-cyclin D/CDK4-Rb pathway is altered in all melanoma cell lines (13). Another important genetic factor in melanoma pathogenesis is the mitogen-activated protein kinase (MAPK) cascade (14). The MAPK and $\mathrm{Rb}$ pathways interconnect at cyclin D1. The cyclin D1 promoter acts as a sensor for growth signals conveyed via the MAPK cascade and provides a link between this pathway and the cell cycle machinery (15). Following treatment with BRAF inhibitors, most patients develop resistance within 6-8 months. The overexpression of cyclin D1, which may be observed in $15-20 \%$ of BRAF-resistant melanomas, is associated with a higher rate of resistance to BRAF inhibitors $(16,17)$. Taken together, NF- $\kappa \mathrm{B}$ activity upregulation and cyclin D1 overexpression have been identified as important factors contributing to melanoma pathogenesis, and inhibition of their expression levels may be beneficial as a treatment for melanoma.

Fructooligosaccharides (FOS) are important prebiotics due to their capacity to selectively stimulate the growth and/or activity of beneficial intestinal microbiota, such as Lactobacillus and Bifidobacterium (18). Commercially available FOS produced from sucrose comprise 1-kestose, nystose and $1^{\mathrm{F}}$-fructosylnystose, which are referring to inulo-type FOS. Neo-FOS may be produced from sucrose through the catalytic action of ${ }^{6} \mathrm{G}$-fructofuranosidase from Xanthophyllomyces dendrorhous. Neo-FOS consist primarily of neokestose (FGF) and neonystose $\left(\mathrm{FGF}_{2}\right)$, in which fructosyl units are $\beta-(2,6)$-linked to the fructofuranose residues of sucrose (19). When compared with inulo-type FOS, neo-FOS exert improved chemical stability and bifidogenetic activity (20).

Our previous study suggested that the antineoplastic effects of neokestose on the Caco- 2 colorectal adenocarcinoma cell line involved inhibition of the expression levels of $\mathrm{NF}-\kappa \mathrm{B}$ and cytochrome $c$ oxidase subunit II (21). The present study investigated the mechanism of neokestose in suppressing human melanoma A2058 cell growth. One mechanism that may contribute to the anticancer properties of neokestose is the downregulation of $\mathrm{NF}-\kappa \mathrm{B}$ signaling. To the best of our knowledge, the present study is the first to suggest that neokestose may inhibit the activity of NF- $\kappa \mathrm{B}$ and the expression of cyclin D1 in the A2058 melanoma cell line in vitro.

\section{Materials and methods}

Preparation of neokestose. Neokestose is the primary FOS produced in cultures of $X$. dendrorhous when grown on sucrose (22). Neokestose (Fig. 1A) was purified from the high purity neo-FOS mixture obtained as previously described (23). Neokestose was purified by high-performance liquid chromatography on a semi-preparative ODS-AQ column (20x250 mm; YMC, Co., Ltd., Kyoto, Japan) with a Waters 410 differential refractive index detector (Waters Corporation, Milford, MA, USA) (21).
Cell culture. The A2058 melanoma cell line was obtained from the Bioresource Collection and Research Center (Hsinchu, Taiwan). The A2058 melanoma cell line was routinely maintained and subcultured in $10 \mathrm{~cm}^{2}$ dishes at $37^{\circ} \mathrm{C}$ in a humidified $\mathrm{CO}_{2}$ incubator, containing $95 \%$ air and $5 \% \mathrm{CO}_{2}$. The medium for cell growth contained $10 \%$ heat-inactivated HyClone fetal bovine serum (SH30071.03; Thermo Fisher Scientific, Inc., Waltham, MA, USA), $100 \mathrm{IU} / \mathrm{ml}$ penicillin and $100 \mathrm{IU} / \mathrm{ml}$ streptomycin in HyClone Dulbecco's modified Eagle's medium (DMEM)/High Glucose solution (SH30243.01; Thermo Fisher Scientific, Inc.). When cells reached $80 \%$ confluence, they were subcultured using $0.25 \%$ trypsin and $0.02 \%$ EDTA in PBS. The medium was replaced every $48 \mathrm{~h}$. Cells were grown in serum-free media for $24 \mathrm{~h}$ prior to treatment with neokestose.

The melanoma cells were plated onto 24 -well plates at a density of 10,000 cells/well and cultured for $24 \mathrm{~h}$. The cells were subsequently serum-starved for $24 \mathrm{~h}$ to synchronize cells in the $G_{0} / G_{1}$ phase of the cell cycle. Neokestose was dissolved in DMEM. The stock solution was diluted to final concentrations of $0,0.25,0.50$ and $2.00 \mathrm{mg} / \mathrm{ml}$ and the treatment was applied for $24 \mathrm{~h}$ for the MTT, cell cycle and apoptosis assays. Neokestose at $1 \mathrm{mg} / \mathrm{ml}$ was used to pretreat A2058 melanoma cells for $2 \mathrm{~h}$, followed by treatment with or without $2.5 \mathrm{ng} / \mathrm{ml}$ tumor necrosis factor- $\beta$ (TNF- $\beta$; 4345-20; BioVision, Inc., Milpitas, CA, USA) for $1 \mathrm{~h}$ for the western blot analysis and immunocytochemistry.

MTT assay. MTT (Sigma-Aldrich; Merck KGaA, Darmstadt, Germany) is a tetrazolium salt that is cleaved by mitochondrial dehydrogenase in living cells. The effects of neokestose $(0,0.25,0.50$ or $2.00 \mathrm{mg} / \mathrm{ml})$ on cell viability were determined using the MTT assay. A2058 melanoma cells were seeded at a density of $1.0 \times 10^{4}$ cells/well in 96-well plates for 2 days, the medium was discarded and $20 \mu \mathrm{l}$ MTT solution $[0.5 \mathrm{mg} / \mathrm{ml}$ in phosphate-buffered saline (PBS)] was added to all wells and the cells were incubated for $3 \mathrm{~h} 37^{\circ} \mathrm{C}$. Subsequently, $100 \mu \mathrm{l}$ dimethyl sulfoxide was added to each well to lyse the cells for $5-10 \mathrm{~min}$ a $37^{\circ} \mathrm{C}$ incubator and the plates were transferred to a microplate reader, where absorbance was read at $595 \mathrm{~nm}$. Based on a previous cytotoxicity test (21), the concentrations of neokestose used in the present study were $0.25,0.50$ and $2.00 \mathrm{mg} / \mathrm{ml}$, and $0 \mathrm{mg} / \mathrm{ml}$ was used as the control. All experiments were performed at least four times with four wells for each concentration.

Cell cycle analysis. To analyze the cell cycle distribution, cells were washed twice with PBS, collected by centrifugation at $725 \mathrm{x} \mathrm{g}$ for $5 \mathrm{~min}$ at $4^{\circ} \mathrm{C}$ and fixed in $70 \%(\mathrm{v} / \mathrm{v})$ ethanol at $4^{\circ} \mathrm{C}$ for $30 \mathrm{~min}$. Following fixation, the cells were esuspended in PBS and stained with propidium iodide (PI) solution $(48 \mu \mathrm{g} / \mathrm{ml}$ PI and $48 \mu \mathrm{g} / \mathrm{ml}$ RNase A) for $20 \mathrm{~min}$ at room temperature. The DNA content of the cells was examined by flow cytometry (Cell Lab Quanta SC flow cytometer; Beckman Coulter, Fullerton, CA, USA) and analyzed by Cell Lab Quanta SC software version 1.0 .

Apoptosis analysis. Apoptosis was quantified using the Annexin V-fluorescein isothiocyanate (FITC) Apoptosis Detection kit I (BD Biosciences, San Jose, CA, USA), according 
to the manufacturer's protocol. The cells were washed twice with PBS and collected by centrifugation at $725 \mathrm{x}$ g for $5 \mathrm{~min}$ at $25^{\circ} \mathrm{C}$. Cells were resuspended in $100 \mu \mathrm{l}$ binding buffer and labeled with $5 \mu \mathrm{l}$ Annexin V FITC and $5 \mu \mathrm{l}$ PI for $15 \mathrm{~min}$ in the dark. Following labeling, cells were resuspended in $400 \mu \mathrm{l}$ binding buffer and detected using the Cell Lab Quanta SC flow cytometer (Beckman Coulter, Fullerton, CA, USA). The multiparametric data were analyzed using the Cell Lab Quanta SC software version 1.0.

Western blot analysis. A2058 melanoma cells were lysed with cell extraction buffer (M-PER Mammalian Protein Extraction reagent; Thermo Fisher Scientific, Inc.). The Bicinchoninic Acid Protein Reagent Assay kit (Thermo Fisher Scientific, Inc.) was used to quantify the protein concentration. The cell protein extracts (60 $\mu \mathrm{g}$ per lane) were separated by $12 \%$ SDS-PAGE. Following electrophoresis, the proteins were transferred onto polyvinylidene fluoride membranes (Hybond-P; GE Healthcare Life Sciences, Little Chalfont, UK). Membranes were blocked with $3 \%$ bovine serum albumin (BSA; Sigma-Aldrich; Merck KGaA) in Tris-buffered saline (20 mM Tris, $\mathrm{pH} 7.5$, and $150 \mathrm{mM} \mathrm{NaCl}$ ) containing $0.1 \%$ Tween-20 (TBST) for $1 \mathrm{~h}$, then the membranes were incubated with the following primary antibodies (all diluted to 1:1,000): Anti-cyclin D1 [rabbit monoclonal antibody (mAb); 2978; Cell Signaling Technology, Inc., Danvers, MA, USA] anti-NF- $\mathrm{B}$ (rabbit mAb; 4764; Cell Signaling Technology, Inc.), anti-p-IкB $\alpha$ (rabbit mAb;2859; Cell Signaling Technology, Inc.) and anti- $\beta$-tubulin (rabbit mAb; 2128; Cell Signaling Technology, Inc.) for $16 \mathrm{~h}$ at $4^{\circ} \mathrm{C}$ and subsequently washed with TBST. The secondary antibody, goat anti-rabbit immunoglobulin $\mathrm{G}$ horseradish peroxidase-conjugated antibody (7074; Cell Signaling Technology, Inc.), was incubated for $1 \mathrm{~h}$ at room temperature with the membranes at a dilution of 1:2,000 in Gelatin-NET (50 $\mathrm{mM}$ Tris, $0.25 \%$ gelatin, $15 \mathrm{mM} \mathrm{NaCl}, 5 \mathrm{mM}$ EDTA $\bullet 2 \mathrm{Na}$, $0.05 \%$ Tween 20, pH 8.0). Following washing three times with PBS, 10 min each, the antibody complexes were detected using the Clarity Western enhanced chemiluminescence substrate (170-5061; Bio-Rad Laboratories, Inc., Hercules, CA, USA) and an ImageQuant LAS 4000 imager (GE Healthcare Life Sciences).

Immunocytochemistry. Immunocytochemistry was used to determine whether TNF- $\beta$ induced NF- $\kappa$ Bp 65 nuclear translocation in A2058 melanoma cells. The A2058 cells were plated onto 24 -well plates at a density of $1 \times 10^{4}$ cells/well, grown in $1 \mathrm{ml}$ culture media and then incubated for $24 \mathrm{~h}$. Following pretreatment with $1 \mathrm{mg} / \mathrm{ml}$ neokestose for $2 \mathrm{~h}$, the cells were stimulated with $2.5 \mathrm{ng} / \mathrm{ml} \mathrm{TNF}-\beta$ for $1 \mathrm{~h}$. Subsequently, the cells were fixed with $4 \%$ paraformaldehyde on slides for $30 \mathrm{~min}$ at room temperature. In order to improve cell adherence, the slides were coated with poly-L-lysine (Sigma-Aldrich; Merck KGaA). Subsequently, the cells were permeabilized with $0.5 \%$ Triton $\mathrm{X}-100$ in PBS. The staining was performed using an anti-NF- $\kappa$ Bp 65 antibody at a dilution of 1:100 (4764; rabbit mAb; Cell Signaling Technology, Inc.) for $1 \mathrm{~h}$ at room temperature. Cells were washed twice with PBS and subsequently incubated at room temperature with a goat anti-rabbit FITC secondary antibody (111-095-046; Jackson ImmunoResearch Laboratories, Inc.,
West Grove, PA, USA) at a dilution of 1:100 for $1 \mathrm{~h}$. Nuclei were stained using Hoechst 33342 (Invitrogen; Thermo Fisher Scientific, Inc.). Cells were subsequently embedded in a mounting medium following two washes with PBS. The slides were then examined under a Leica TCS SP5 Confocal Spectral Microscope Imaging system (Leica Microsystems, GmbH, Wetzlar, Germany).

Statistical analysis. Results of MTT assays and flow cytometric analyses were expressed as the mean \pm standard error. One-way analysis of variance was used and the identification of significant differences between results were performed by applying the Duncan test, with the level of statistical significance set at $\mathrm{P}<0.05$. $\mathrm{P}<0.05$ was considered to indicate a statistically significant difference.

\section{Results}

Neokestose exerts a negative effect on A2058 cell viability. The effects of various concentrations of neokestose $(0.25,0.50$ and $2.00 \mathrm{mg} / \mathrm{ml} ; 0 \mathrm{mg} / \mathrm{ml}$ was used as the control) were determined on the viability of A2058 melanomacells using MTT assay. For each experiment, at least three independent experiments were performed and each was repeated in triplicate in 96-well plates. Treatment of A2058 melanoma cells with increasing concentrations of neokestose exerted a significant dose-dependent cytotoxic effect (Fig. 1B).

Effects of neokestose on cell cycle distribution. A2058 melanoma cells were treated with neokestose $(0.25,0.50$ and $2.00 \mathrm{mg} / \mathrm{ml} ; 0 \mathrm{mg} / \mathrm{ml}$ was used as the control) for $24 \mathrm{~h}$ and the cell cycle distribution was quantified using flow cytometry. Neokestose treatment significantly increased the sub- $\mathrm{G}_{1}$ phase cell population (Fig. 2).

Effects of neokestose on A2058 cell apoptosis. A2058 melanoma cells treated with neokestose were analyzed using Annexin V-FITC/PI staining and flow cytometry in order to investigate whether apoptosis was induced by neokestose (Fig. 3). Neokestose treatment significantly increased the percentage of early and late apoptotic cells (Fig. 3B), indicating that neokestose was able to induce both early and late stage apoptosis of A2058 melanoma cells. In addition, neokestose exposure induced apoptosis of A2058 melanoma cells in a dose-dependent manner (Fig. 3).

Effects of neokestose on the expression of $p-I \kappa B$ and cyclin DI in the presence of TNF- $\beta$. The present study demonstrated that exposure to $2.5 \mathrm{ng} / \mathrm{ml} \mathrm{TNF}-\beta$ (an NF- $\kappa \mathrm{B}$ activator) for $1 \mathrm{~h}$ led to increased expression of $\mathrm{p}-\mathrm{I} \kappa \mathrm{B}$ and cyclin D1. Fig. 4 indicates increased expression of $\mathrm{p}-\mathrm{I} \kappa \mathrm{B}$ and cyclin D1. Pretreatment with $1 \mathrm{mg} / \mathrm{mlneokestose}$ resulted in reduced expression of $\mathrm{p}-\mathrm{I} \kappa \mathrm{B}$ and cyclin D1 in TNF- $\beta$-exposed A2058 melanoma cells.

Neokestose inhibits TNF- $\beta$-induced NF- $\kappa B$ p 65 nuclear translocation. Following exposure to $2.5 \mathrm{ng} / \mathrm{ml} \mathrm{TNF}-\beta$ for $1 \mathrm{~h}, \mathrm{NF}-\kappa \mathrm{B}$ nuclear translocation was increased in A2058 melanoma cells. However, following treatment with $1 \mathrm{mg} / \mathrm{ml}$ neokestose for $2 \mathrm{~h}$ and then $2.5 \mathrm{ng} / \mathrm{ml} \mathrm{TNF}-\beta$ for $1 \mathrm{~h} \mathrm{NF- \kappa B}$ nuclear translocation was reduced (Fig. 5). 
A

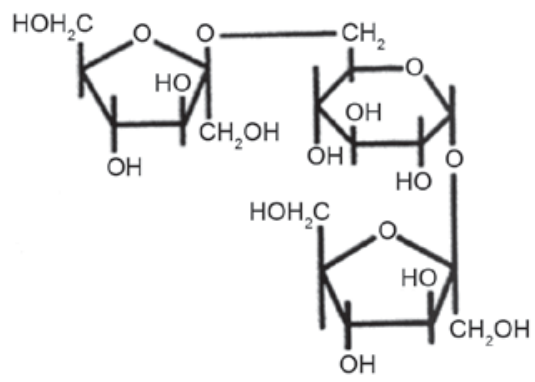

Neokestose

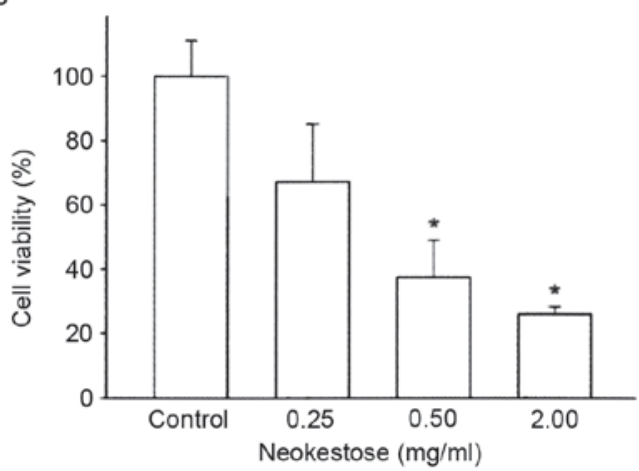

Figure 1. Inhibition of A2058 melanoma cell viability following treatment with neokestose. (A) Chemical structure of neokestose. (B) Cell viability of A2058 melanoma cells following treatment with increasing doses of neokestose. Neokestose exerted a significantly cytotoxic effect. "P<0.05 vs. control group.
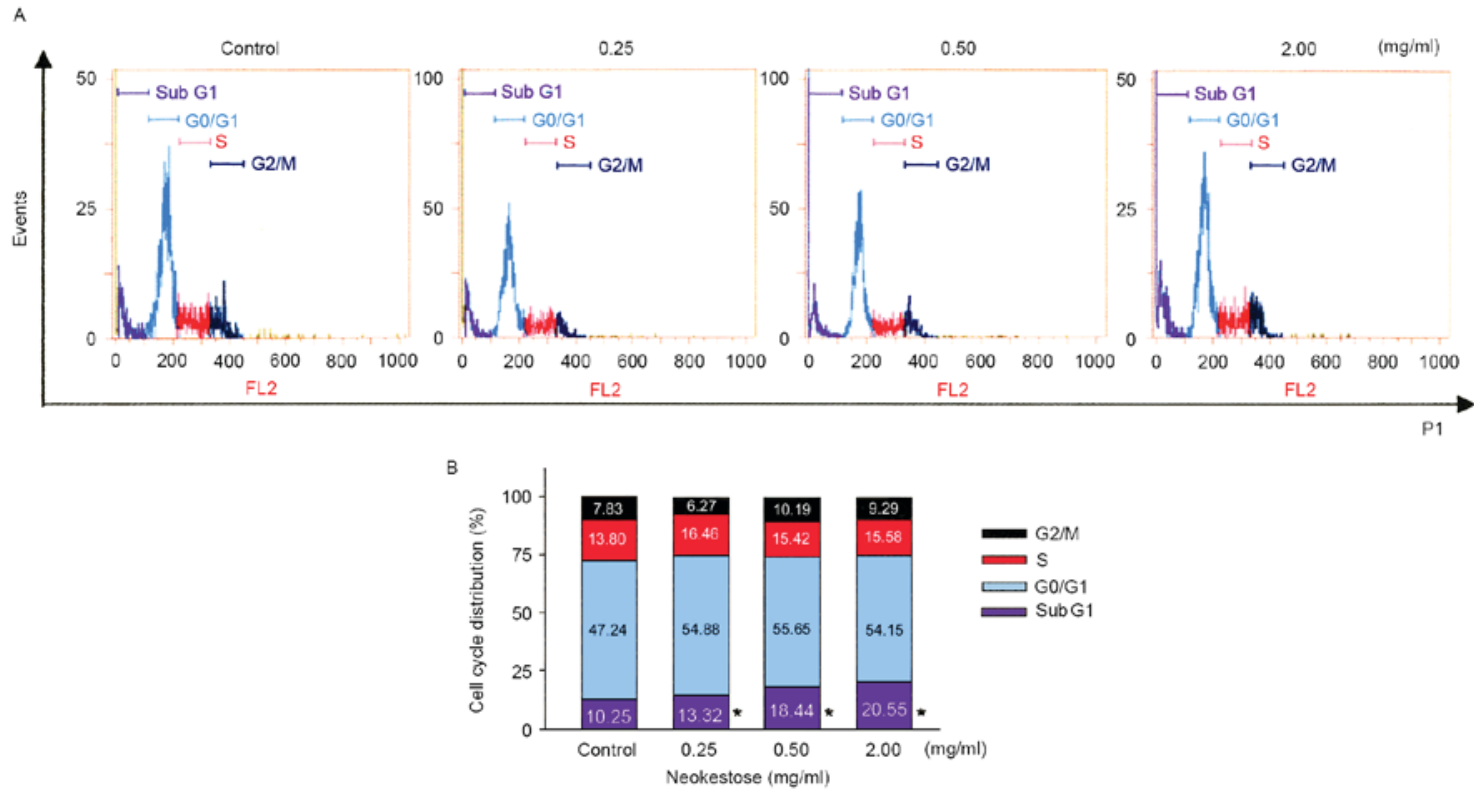

Figure 2. Effects of neokestose on cell cycle distribution of A2058 melanoma cells treated with $0.25,0.50$ and $2.00 \mathrm{mg} / \mathrm{ml}$ neokestose; A2058 melanoma cells without neokestose treatment were used as the control group. (A) A2058 melanoma cells were stained with propidium iodide and their DNA content was analyzed by flow cytometry. (B) Data are the mean of four independent experiments. "P<0.05 vs. control group.
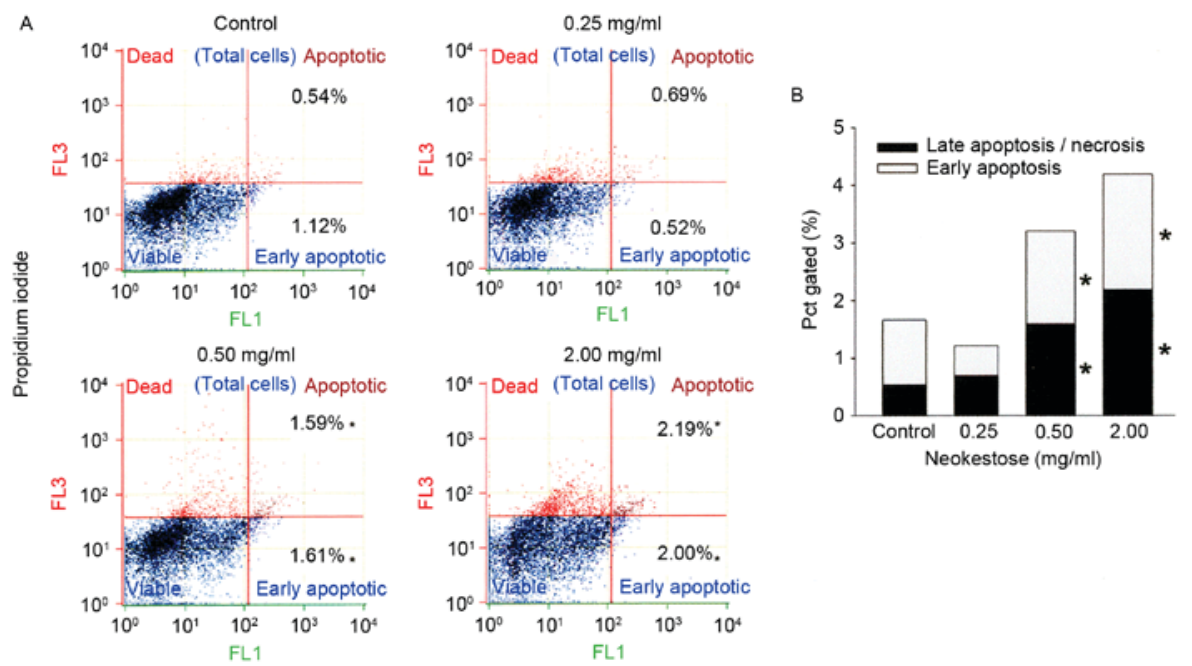

Annexin V-FITC

Figure 3. Neokestose induced apoptosis in A2058 melanoma cells. (A) A2058 melanoma cells were treated with 0, 0.25, $0.50 \mathrm{and} 2.00 \mathrm{mg} / \mathrm{ml}$ for $24 \mathrm{~h}$. The cells were double-stained with Annexin V-FITC and propidium iodide and were analyzed by flow cytometry. (B) Early and late apoptotic cells increased following treatment with 0.50 and $2.00 \mathrm{mg} / \mathrm{ml}$ neokestose. ${ }^{*} \mathrm{P}<0.05$ vs. control group. FITC, fluorescein isothiocyanate. 


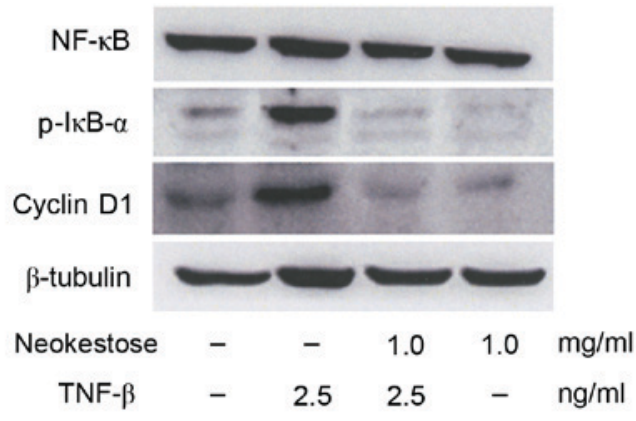

Figure 4 . Western blotting revealed that $1 \mathrm{~h}$ treatment with TNF- $\beta$ led to increased $\mathrm{p}-\mathrm{I} \kappa \mathrm{B}$ and cyclin D1 expression. However, pretreatment with neokestose led to reduced expression of $\mathrm{p}-\mathrm{I} \kappa \mathrm{B}$ and cyclin D1.p-IкB, phosphorylated-inhibitor of $\kappa \mathrm{B}$; TNF- $\beta$, tumor necrosis factor $\beta$; NF- $\kappa \mathrm{B}$, nuclear factor- $\kappa \mathrm{B}$.

A

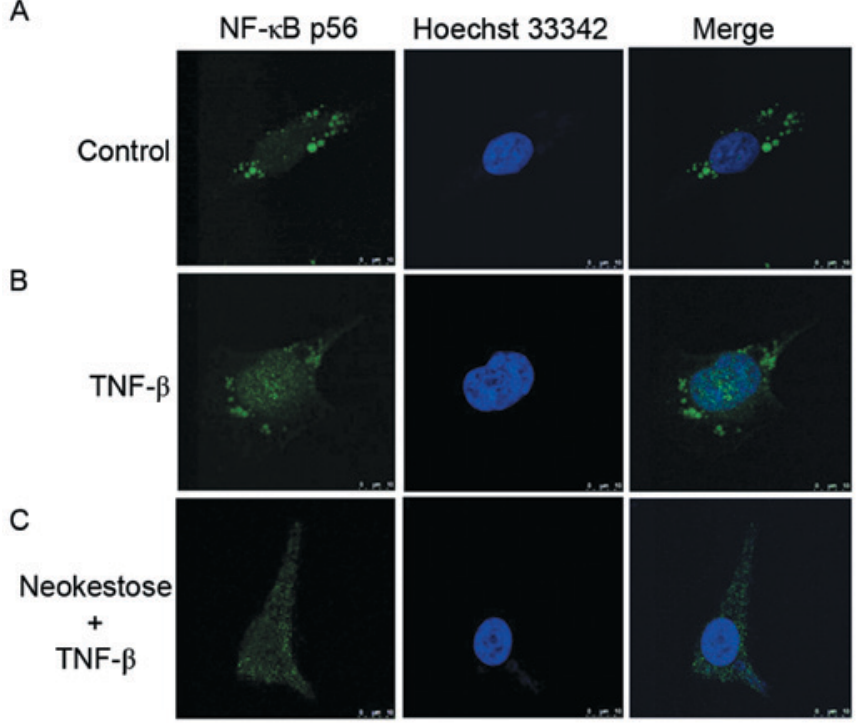

Figure 5. Immunocytochemical analysis of the effects of neokestose on the inhibition of NF- $\mathrm{kB}$ p 65 nuclear translocation in A2058 melanoma cells. (A) Control cells were not treated with neokestose or TNF- $\beta$. (B) Cells were treated with $2.5 \mathrm{ng} / \mathrm{ml} \mathrm{TNF}-\beta$ for $1 \mathrm{~h}$. (C) Cells were treated with $1 \mathrm{mg} / \mathrm{ml}$ neokestose for $2 \mathrm{~h}$ followed by $2.5 \mathrm{ng} / \mathrm{ml}$ TNF- $\beta$ for $1 \mathrm{~h}$. Nuclear translocation of NF-kB p65 was detected by fluorescein isothiocyanate-labeled anti-p65 antibody and analyzed using confocal microscopy. The cells were also stained with Hoechst 33342 for nuclear detection. TNF- $\beta$, tumor necrosis

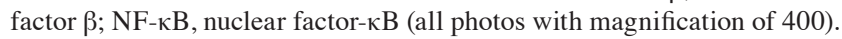

\section{Discussion}

It is well known that $\mathrm{NF}-\kappa \mathrm{B}$ is conjugated to $\mathrm{I} \kappa \mathrm{B}$ residues in the cytoplasm, where it maintains an inactive state (24). Treatment of cells with TNF- $\beta$ may increase NF- $\kappa$ B activation, which leads to the phosphorylation of $\mathrm{I} \kappa \mathrm{B}$. Previous studies have suggested that inhibition of this pathway may lead to the suppression of tumor growth $(21,25)$. NF- $\kappa \mathrm{B}$ activation requires the phosphorylation, ubiquitinationand subsequent degradation of $\mathrm{I} \kappa \mathrm{B}$. One primary mechanism of $\mathrm{NF}-\kappa \mathrm{B}$ inactivation is through inhibition of $\mathrm{I} \kappa \mathrm{B}$ phosphorylation, leading to the retention of $\mathrm{NF}-\kappa \mathrm{B}$ in the cytoplasm. Neokestose may prevent $\mathrm{I} \kappa \mathrm{B}$ phosphorylation, thus reducing $\mathrm{NF}-\kappa \mathrm{B}$ activation.

The NF- $\mathrm{BB}$ signaling pathway can be potentially targeted at various levels, including kinases, phosphatases, DNA binding proteins, acetyl transferases and methyl transferases, in addition to ubiquitination and nuclear translocation. It is estimated that $>700$ compounds exist that inhibit $N F-\kappa B$ activity; therefore, the NF- $\kappa \mathrm{B}$ signaling pathways have been targeted at various levels for effective cancer therapy (26).

It has previously been reported that specific compounds work on the level of nuclear translocation of $\mathrm{NF}-\kappa \mathrm{B}$; for example, SN50 is a 41-residue synthetic peptide that may effectively inhibit lipopolysaccharide- and TNF- $\alpha$-induced $\mathrm{NF}-\kappa \mathrm{B}$ nuclear translocation in intact cells (27). In addition, the fungal compound dehydroxymethylepoxyquinomicin may inhibit TNF- $\alpha$-induced nuclear translocation and $N F-\kappa B$ activation (28). Furthermore, C086, which is a novel analog of curcumin, may inhibit $\mathrm{I} \kappa \mathrm{B} \alpha$ phosphorylation and suppress the nuclear translocation of NF- $\mathrm{NB}(29)$.

Since the aforementioned compounds may exert adverse side effects and are too costly to be widely implemented they may not be used as dietary chemopreventive agents. Therefore, it is necessary to identify cheaper and safer compounds to be used as chemopreventive agents for cancer. In this regard neokestose is considered to be a cheaper and safer compound, although future in vivo studies are required before neokestose can be widely used as a dietary chemopreventive agent.

In conclusion, the findings of the present study revealed that neokestose may inhibit the $\mathrm{NF}-\kappa \mathrm{B}$ signaling pathway and cyclin D1 expression in A2058 melanoma cells.

\section{Acknowledgements}

The authors would like to thank the Hsin Shen Junior College of Medical Care and Management, Tatung University and Taipei Medical University for their assistance in academic resources.

\section{References}

1. Eggermont AM, Spatz A and Robert C: Cutaneous melanoma. Lancet 383: 816-827, 2014.

2. Mashima E, Inoue A, Sakuragi Y, Yamaguchi T, Sasaki N, Hara Y, Omoto D, Ohmori S, Haruyama S, Sawada Y, et al: Nivolumab in the treatment of malignant melanoma: Review of the literature. Onco Targets Ther 8: 2045-2051, 2015.

3. Robert C, Dummer R, Gutzmer R, Lorigan P, Kim KB, Nyakas M, Arance A, Liszkay G, Schadendorf D, Cantarini M, et al: Selumetinib plus dacarbazine versus placebo plus dacarbazine as first-line treatment for BRAF-mutant metastatic melanoma: A phase 2 double-blind randomised study. Lancet Oncol 8: 733-740, 2013.

4. Larkin J, Ascierto PA, Dréno B, Atkinson V, Liszkay G, Maio M, Mandalà M, Demidov L, Stroyakovskiy D, Thomas L, et al: Combined vemurafenib and cobimetinib in BRAF-mutated melanoma. N Engl J Med 20: 1867-1876, 2014.

5. Niezgoda A, Niezgoda P and Czajkowski R: Novel Approaches to treatment of advanced melanoma: A review on targeted therapy and immunotherapy. Biomed Res Int 2015: 851387, 2015.

6. Gandini S, Sera F, Cattanizza MS, Pasquini P, Picconi O, Boyle P and Melchi CF: Meta-analysis of risk factors for cutaneous melanoma: II. Sun exposure. Eur J Cancer 41: 45-60, 2005.

7. Dhawan P, Singh AB, Ellis DL and Richmond A: Constitutive activation of Akt/protein kinase B in melanoma leads to up-regulation of nuclear factor-kappaB and tumor progression. Cancer Res 62: 7335-7342, 2002

8. McNulty SE, Tohidian NB and Meyskens FL Jr: RelA, p50 and inhibitor of kappa B alpha are elevated in human metastatic melanoma cells and respond aberrantly to ultraviolet light B. Pigment Cell Res 14: 456-465, 2001. 
9. McNulty SE, del Rosario R, Cen D, Meyskens FL Jr and Yang S: Comparative expression of NFkappaB proteins in melanocytes of normal skin vs. benign intradermal naevus and human metastatic melanoma biopsies. Pigment Cell Res 17: 173-180, 2004.

10. Schmitz ML, Mattioli I, Buss H and Kracht M: NF-kappaB: A multifaceted transcription factor regulated at several levels. Chembiochem 5: 1348-1358, 2004.

11. Gilmore TD: Introduction to NF-kappaB: Players, pathways, perspectives. Oncogene 51: 6680-6684, 2006.

12. Sherr CJ and Roberts JM: CDK inhibitors: Positive and negative regulators of G1-phase progression. Genes Dev 13: 1501-1512, 1999.

13. Bartkova J, Lukas J, Guldberg P, Alsner J, Kirkin AF, Zeuthen J and Bartek J: The p16-cyclin D/Cdk4-pRb pathway as a functional unit frequently altered in melanoma pathogenesis. Cancer Res 56: 5475-5483, 1996.

14. Chin L, Merlino G and DePinho RA: Malignant melanoma: Modern black plague and genetic black box. Genes Dev 12 3467-3481, 1998.

15. Filmus J, Robles AI, Shi W, Wong MJ, Colombo LL and Conti CJ: Induction of cyclin D1 overexpression by activated ras. Oncogene 9: 3627-3633, 1994.

16. Sullivan RJ and Flaherty KT: Resistance to BRAF-targeted therapy in melanoma. Eur J Cancer 6: 1297-1304, 2013

17. Sauter ER, Yeo UC, von Stemm AV, Zhu W, Litwin S, Tichansky DS, Pistritto G, Nesbit M, Pinkel D, Herlyn M and Bastian BC: Cyclin D1 is a candidate oncogene in cutaneous melanoma. Cancer Res 62: 3200-3206, 2002.

18. Gibson GR and Roberfroid MB: Dietary modulation of the human colonic microbiota: Introducing the concepts of prebiotics. J Nutr 125: 1401-1412, 1995.

19. Lim JS, Lee JH, Kang SW, Park SW and Kim SW: Studies on production and physical properties of neo-FOS produced by co-immobilized Penicillium citrinum and neo-fructosyltransferase. Eur Food Res Technol 225: 457-462, 2007.
20. Kilian S, Kritzinger S, Rycroft C, Gibson G and du Preez J: The effects of the novel bifidogenic trisaccharide, neokestose, on the human colonic microbiota. World J Microbiol Biotechnol 18: 637-644, 2002

21. Lee SM, Chang JY, Wu JS and Sheu DC: Antineoplastic effect of a novel chemopreventive agent, neokestose, on the Caco- 2 cell line via inhibition of expression of nuclear factor $-\kappa \mathrm{B}$ and cyclooxygenase-2. Mol Med Rep 12: 1114-1118, 2015.

22. Kritzinger SM, Kilian SG, Potgieter MA and de Preez JC: The effect of production parameters on the synthesis of the prebiotic trisaccharide, neokestose, by Xanthophyllomyces dendrorhous (Phaffia rhodozyma). Enzyme Microb Technol 32: 728-737, 2003.

23. Sheu DC, Chang JY, Chen YJ and Lee CW: Production of high-purity neofructooligosaccharides by culture of Xanthophyllomyces dendrorhous. Bioresour Technol 132: 432-435, 2013

24. Ghosh S and Karin M: Missing pieces in the NF-kappaB puzzle. Cell 109 (Suppl): S81-S96, 2002

25. Luqman S and Pezzuto JM: NFkappaB: A promising target for natural products in cancer chemoprevention. Phytother Res 24 949-963, 2010.

26. Gupta SC, Sundaram C, Reuter S and Aggarwal BB: Inhibiting $\mathrm{NF}-\kappa \mathrm{B}$ activation by small molecules as a therapeutic strategy. Biochim Biophys Acta 1799: 775-787, 2010.

27. Lin YZ, Yao SY, Veach RA, Torgerson TR and Hawiger J Inhibition of nuclear translocation of transcription factor NF-kappa B by a synthetic peptide containing a cell membrane-permeable motif and nuclear localization sequence. J Biol Chem 270: 14255-14258, 1995.

28. Ariga A, Namekawa J, Matsumoto $\mathrm{N}$, Inoue $\mathrm{J}$ and Umezawa $\mathrm{K}$ : Inhibition of tumor necrosis factor-alpha-induced nuclear translocation and activation of NF-kappa B by dehydroxymethylepoxyquinomicin. J Biol Chem 277: 24625-24630, 2002.

29. Chen C, Liu Y, Chen Y and Xu J: C086, a novel analog of curcumin, induces growth inhibition and down-regulation of $\mathrm{NF \kappa B}$ in colon cancer cells and xenograft tumors. Cancer Biol Ther 12: 797-807, 2011. 